\title{
Pola Penguasaan Tanah Ajun Arah Dan Pelaksanaan Pendaftaran Tanah Sistematik Lengkap Di Kota Sungai Penuh
}

\author{
Windarto, Isran Idris, TaufikYahya \\ Fakultas Hukum, Universitas Jambi, Indonesia \\ Email: mas_wiend@unja.ac.id
}

\begin{abstract}
ABSTRAK
Ajun arah adalah ketentuan adat dalam tata cara mendirikan rumah baik diatas tanah pribadi maupun tanah negeri di Kabupaten Kerinci atau Kota Sungai Penuh, untuk mohon izin dan pengarahan dari pemangku adat untuk mengajun mengarahkan, mematok tanah yan diminta oleh masyarakat atau masyarakat persekutuan hukum adat. Tujuan penelitian adalah: 1.Untuk mengetahui bagaimanakah pola penguasaan tanah ajun arah pada masyarakat hukum adat Kota Sungai Penuh, 2. Untuk mengetahui bagaimanakah pelaksanaan Pendaftaran Tanah Sistem Lengkap terhadap tanah ajun arah di Kota Sungai Penuh. metodologi yang digunakan dalam penelitian ini ialah pengamatan, wawancara, studi literatur. Hasil penelitian ; 1. Tanah ajun arah adalah tanah negeri atau tanah ulayat yang diatur oleh lembaga adat dan dikuasai oleh pemangku adat yang ditetapkan oleh depati dan ninik mamak, alim ulama, orang tuo cerdik pandai melalui musyawarah adat. Pola penguasaan tanah ajun arah dipengaruhi oleh sistem kekerabatan matrilinial yang membedakan antara anak laki-laki dan perempuan. Tanah ajun arah adalah tanah negeri yang boleh dipakai oleh anak batino saja untuk mendirikan rumah. Penguasaan tanah tersebut masih berlangsung sepanjang masih terbukti secara fisik sesuai dengan peruntukannya. 2. Hukum Agraria Nasional Indonesia membenarkan adanya penguasaan tanah secara hukum adat termasuk tanah ajun arah sepanjang tidak bertantangan dengan praturan perundangan yang ada diatasnya, dan tidak bertantangan dengan kepentingan bangsa dan negara. Pelaksanaan program pemerintah Indonesia dalam rangka Pendaftaran Tanah Sistem Lengkap tetap terlaksana walaupun hanya sampai pada tahap pemetaan, karena tanah ajun arah bukanlah tanah individu, dan tanah ajun arah masih bisa diberikan oleh pemangku adat kepada orang lain bila peruntukan untuk mendirikan rumah tersebut tidak kelihatan lagi. Kondisi ini menyebabkan sulit untuk menentukan kepastian hukum tentang subjek hukum sebagai salah satu sarat untuk Pendaftaran Tanah Sistem Lengkap di Kota Sungai Penuh. Suatu hal positif pada pola penguasa tanah ajun arah ini, menyebabkan tanah adat tidak beralih kepada pihak diluar persekutuan hukum adat, karena orang diluar persekutan hukum adat tidak punya hak untuk menguasai dan memiliki tanah ajun arah.
\end{abstract}

Kata Kunci: Tanah Ajun Arah, Pendaftaran Tanah, Kepastian Hukum

\section{PENDAHULUAN}

Pengaturan pertanahan di Indonesia dalam konstitusi adalah bukti pertanahan adalah masalah yang sangat penting bagi negara dan masyarakat dengan segala aspek kehidupannya. Untuk tercapainya kepastian dan ketertiban hukum pertanahan di Indonesia maka diatur di dalam Pasal 33 ayat (3) Undang-undang Dasar 1945, “ Bumi dan air dan kekayaan alam yang terkandung di dalamnya dikuasai oleh negara dan dipergunakan untuk sebesar-besarnya kemakmuran rakyat". Kemudian Pasal 33 ayat (3) Undang-undang Dasar 1945 tersebut dijabarkan dalam Undang-undang Nomor 5 Tahun 1960 tentang Peraturan Dasar Pokok-pokok Agraria, yang lebih dikenal dengan Undang-undang Pokok Agraria atau UUPA yang menjadi 
dasar hukum bagi negara Republik Indonesia untuk mengatur dan menyelenggarakan pertanahan di nusantara ini.

Menurut Effendi Peranginang, "Undang-undang Nomor 5 Tahun 1960 pada dasarnya bertujuan :

1. Meletakkan dasar-dasar bagi penyusunan hukum agraria nasional yang merupakan alat untuk membawa kemakmuran, kebahagian dan keadilan bagi rakyat dan negara, terutama kepada para para petani dalam rangka mencapai masyarakat yang adil dan makmur.

2. Meletakan dasar-dasar untuk mengadakan kesatuan dan keserdehanaan dalam hukum pertanahan,

3. Meletakan dasar-dasar untuk memberikan kepastian hukum mengenai hak-hak atas tanah bagi rakyat seluruhnya"

Kemudian Pasal 2 UUPA mengatur lebih lanjut tentang kewenangan Negara terhadap tanah di Indonesia. Pertanahan adalah permasalahan yang sangat konflek dan sangat erat hubungannya dengan kehidupan manusia, dan bagi negara negara agraris masalah tanah pada hakekatnya adalah masalah fondamental, yang menyangkut semua persoalan kehdupan manusia. Benyamin White menyatakan;"masalah penguasaan tanah bukanlah masalah sederhana, karena terkait bukan saja dalam hubungan antara manusia dengan tanah, melainkan juga antar manusia dengan manusia"2

Menurut Peter Doner "Sistem penguasaan tanah mencakup pengaturan-pengaturan secara legal maupun secara adat yang dengan pelaku pelaku dalam usaha tani memperoleh jangkauan terhadap kesempatan -kesempatan produktif atas tanah. Ia merupakan hak-hak, kewajibankewajiban, kebebasan-kebebasan dan penampilan dari individu-individu atau kelompokkelompok dalam penggunaan dan pengawasan atas tanah".3

Pendapat ini sesuai dengan Pasal 3 dan Pasal 5 UUPA dan berdasarkan pasal-pasal tersebut maka hukum adat sah diperlakukan dalam masyarakat sepanjang tidak bertantangan dengan kepentingan nasional dan negara dan peraturan yang ada diatasnya. Apabila terjadi sebaliknya, maka ketentuan hukum yang ada diatasnya, kepentingan negara dan bangsa harus didahulukan. Kepatuhan terhadap hukum tanah adat masih tetap berlangsung di tengah-tengah masyarakat. Pemangku adat yang merupakan pejabat adat dalam pengaturan pertanahan masih tetap menjalankan fungsinya. Hak-hak atas tanah adat masih ada seperti hak individu, hak komunal, hak ulayat, hak sewa, bagi hasil, dan lain-lain.

Hukum adat dalam masyarakat Kota Sungai Penuh telah mengatur hubungan persekutuan dan anggotanya dengan tanah. Hukum tanah adat menggariskan hak-hak yang berkenaan dengan tanah ulayat, hak milik perseorangan, pengaturan hak sewa, hak pakai, hak gilir ganti sawah, dan tanah arah ajun. Menurut Idris Djakfar "Ketentuan pengaturan hukum tanah adat di Kerinci /Kota Sungai Penuh telah ada sejak lahirnya Negara Segindo Alam Kerinci, dan pada akhir abad ke 13 dilanjutkan oleh Negara Depati Empat Alam Kerinci hingga sampai permulaan abad ke 20 ". Salah satu pengaturan hukum tanah adat yang masih berlaku sampai saat ini adalah pola penguasaan tanah ajun arah. Tanah ajun arah adalah tanah ulayat di sebuah negeri dalam lawang berkutub dua, parit yang bersudut empat. Tanah ini dikuasai oleh pemangku adat dan ditetapkan oleh depati ninik mamak, alim ulama, orang tua cerdik pandai melalui musyawarah. Tanah ajun arah merupakan tanah yang diatur oleh lembaga adat seperti

\footnotetext{
${ }^{1}$ Effendi Peranginangin, Himpunan Peraturan Hukum Agraria, Jakarta, Esa Study Club, 1979, h.33

${ }^{2}$ Benyamin White dkk, Makalah disampaikan dalam Lokakarya Hukum Tanah, untuk Lembaga-lembaga Swasta Pembina Swadaya Masyarakat Desa, diselenggarakan oleh Sekretariat Bina Desa bekerjasama dengan HKTI, Jakarta 28 Maret 1980

${ }^{3}$ Peter Doner, Land Reform and Economic Develop, Penguin Books Australia Ltd, 1972, h17

${ }^{4}$ Idris Djakfkar, Laporan Penelitian Hukum Waris Masyarakat Kerinci, Fakultas Hukum Universitas Jambi, 1992 h 53
} 
diajun dan di arah oleh para nenek mamak untuk mendirikan rumah. Depati dan nenek mamaklah yang mengajun mengarahkan/ mematok tanah yang diminta oleh oleh masyarakat persekutu hukum adat. Hak tanah ajun arah melekakat pada seseorang sepanjang perutuntukannya masih ada. Suatu hal yang perlu mendapat perhatian pada tanah ajun arah adalah tidak kelihatan dengan tegas penguasaan dan kepepemilkan antara subjek hukum dan objek hukum baik secara fisik dan yuridis. Sedangkan Hukum Agraria Nasional Indonesia menghendaki adanya kepastian hukum, kepastian akan subjek hukum, kepastian akan objek hukum, kepastian perbuatan hukum, dan kepastian akan hubungan hukum. Kepastian hukum tersebut didapatkan melalui pendaftaran tanah, sehingga jelas penguasan tanah baik secara fisik dan yuridis.

Pemerintah yang menggunakan sistem pendaftaran negatif yaitu lebih cendrung menggunakan pendaftaran cara sporadik terasa sangat lamban untuk melakukan pendaftaran tanah. Pada tahun 2016 Pemerintah Indonesia membuat kebijakan percepatan pendaftaran tanah dengan mengeluarkan Peraturan Mentri Agraria dan Tata Ruang/ Kepala Badan Pertanahan Republin Indonesia Nomor 35 Tahun 2016 tentang Percepatan Pelaksanaan Pendaftaran Tanah Sistem Lengkap. Program ini lebih populer dengan istilah PTSL. PTSL adalah proses pendaftaran tanah untuk pertama kali, yang dilakukan secara serentak dan meliputi semua objek pendaftaran tanah yang belum didaftarkan di dalam suatu wilayah desa atau kelurahan atau nama lainnya yang setingkat dengan itu. PTSL adalah wujud pelaksanaan kewajiban dan tanggung jawab pemerintah untuk memberikan kepastian, ketertiban dan perlindungan hukum atas kepemilikan tanah masyarakat. Walaupun PTSL telah memberikan kemudahan bagi masyarakat dalam pendaftaran tanah termasuk membebaskan semua biaya atau gratis, namun demikian tidak semua PTS bisa dilaksanakan. Salah satu sebab adalah menyangkut pola penguasaan dan pemilikan tanah yang berdasarkan Hukum Adat lokal seperti tanah Ajun Arah di Kota Sungai Penuh.

\section{Rumusan Masalah}

Berdasarkan hal itu maka perlu dikaji untuk mensinkronkan kedua kepentingan tersebut agar tuntutan hukum dan kebutuhan masyakar sekarang dalam mengantisipasi dan penyelesaian konflik pertanahan dapat dipenuhi. Untuk itu perlu dirumuskan beberapa hal untuk diteliti :

1. Bagaimanakan pola penguasaan tanah ajun arah pada masyarkat hukum adat Kota Sungai Penuh?

2. Bagaimanakah pelaksanaan Pendaftaran Tanah Sistem Lengkap terhadap tanah ajun arah di Kota Sungai Penuh?

\section{METODOLOGI PENELITIAN}

\section{Pendekatan Penelitian}

Peter Mahmud Marzuki menyatakan ada empat pendekatan dalam penelitian hukum, yaitu pendekatan undang-undang (statute approach), pendekatan kasus (case approach), pendekatan historis (historical approach), dan pendekatan konseptual (conceptual approach).

Pendekatan undang-undang (statute approach) dilakukan dengan menelaah semua undang-undang dan regulasi yang bersangkut paut dengan isu hukum yang sedang ditangani. Bagi penelitian untuk kegiatan praktis, pendekatan undang-undang ini akan membuka kesempatan bagi peneliti untuk mempelajari adakah konsistensi atau kesesuaian antara undangundang dengan undang-undang lainnya atau antara undang-undang dan udang-undang dasar atau antara regulasi dan undang-undang.

Pendekatan kasus (case approach) dilakukan dengan cara melakukan telaah terhadap kasus yang berkaitan isu yang dihadapi yang telah menjadi putusan pengadilan yang telah 
mempunyai kekuatan hukum tetap. Kajian pokok dalam pendekatan kasus adalah ratio decidendi atau reasioning pertimbangan pengadilan untuk sampai kepada suatu putusan.

Pendekatan historis (historical approach) dilakukan dengan menelaah latar belakang apa yang dipelajari dan perkembangan pengaturan mengenai isu yang dihadapi. Pendekatan historis ini diperlukan kalau memang peneliti menganggap bahwa pengungkapan filosopis dan pola pikir ketika sesuatu yang dipelajari itu dilahirkan memang mempunyai relevansi dengan masa kini.

Adapun pendekatan konseptual (coceptual approach) adalah suatu pendekatan yang beranjak dari pandangan-pandangan dan doktirin dktrin yang berkembang di dalam ilmu hukum. Dengan mempelajari pandangan-pandangan dan doktrin-dokrin di dalam ilmu hukum. Dengan mempelajari pandangan-pandangan dan doktrin- doktrin di dalam ilmu hukum, peneliti akan menemukan ide-ide yang melahirkan pengertian-pengertian hukum, konsepkonsep hukum dan azas-azas hukum yang relevan dengan isu yang dihadapi.

Dalam penelitian ini pendekatan masalah digunakan adalah pendekatan undang-undang (normatif approach) sehingga pengkajiannya didasarkan pada peraturan perundang-undangan dan pendekatan konseptual (conceptual approach) untuk pemahaman tentang konsep-konsep yang digunakan dalam penelitian ini.

\section{HASIL DAN PEMBAHASAN}

\section{Pola Penguasaan Tanah Ajun Arah.}

Menurut Hardjito Notopuro dalam buku Abdurrahman "Hukum adat adalah hukum tidak tertulis, hukum kebiasaan dengan ciri khas yang merupakan pedoman rakyat yang menyelenggarakan tata keadilan dan kesejahteraan dan bersifat kekeluargaan" 5

Menurut Soepomo yang dikutip oleh Jaren Saragih "Hukum adat sebagai hukum yang tidak tertulis di dalam peraturan-peraturan legislatif (unstatutory law) meliputi peraturanperaturan hidup yang meskipun tidak ditetapkan oleh yang berwajib, toh ditaati dan didukung oleh rakyat berdasarkan atas keyakinan bahwa sahnya peraturan-peraturan tersebut mempunyai kekuatan hukum"6

Pertanahan adalah salah satu yang diatur dalam hukum adat dan sangat penting, karena menyangkut hayat hidup orang banyak, baik dari segi kemanfaatan ekonomi, tempat tinggal dan dikuburkan secara turun temurun, dan menyangkut dengan roh nenek moyang mereka, yang menyebabkan hubungan mereka dengan tanah juga bersifat religius magis. Dalam pemanfaatan tanah berlaku suatu norma yang mengatur tentang pemilikan dan penguasaan baik secara individu maupun kelompok. Norma tersebut terdiri dari norma yang ideal sampai yang bersifat kongkrit, dijalankan oleh fungsionaris adat, yang menimbulkan hubungan hukum antara masyarakat dan wilayahnya, dan juga adanya pengakuan hak-hak perseorangan atas tanah. Pengaturan tersebut menimbulkan jenishak atas tanah antara lain :

1. Hak Ulayat, yaitu hak desa menurut adat dan kemauannya untuk menguasai tanah tanah dalam lingkungannya daerahnya buat kepentingan anggotanya atau untuk kepenting orang lain (orang asing) dengan membayar kerugian kepada desa dalam hal mana desa itu sedikit banya turut campur dengan pembukaan tanah itu dan turut bertanggung jawab terhadap perkara-perkara yang terjadi di situ yang belum dapat diselesaikan. Tanah ulayat merupakan satu kesatuan hak atas tanah dan mempunyai dasar keagamaan, yang dimiliki oleh oleh persekutuan hukum, dan mengatur tentang hak-hak perseorangan. Menurut Iman Sudiyat " ciri-ciri tanah ulayat antara lain :

\footnotetext{
${ }^{5}$ Abdurrahman, SH., Hukum Adat Menurut Perundang-undangan Republik Indonesia, Cendana Press, Jakarta, 1984, hal 19

${ }^{6}$ Jaren Saragih, Pengantar Hukum Adat, Edisi II, Taristo, Bandung, 1984, hal 13
} 
a. Persekutuan dan anggotanya berhak untuk memanfaatkan tanah memungut hasil dari segala sesuatu yang adala di dalam tanah dan yang tumbuh dan hidup diatas tanah ulayat.

b. Hak individu diliputi oleh hak persekutuan yang bersifat timbal balik, semakin kuat hak individu atas tanah, semakin lemah persekutuannya dan begitu pula sebaliknya.

c. Pimpinan persekutuan dapat menentukan untuk menyatakan dan menggunakan bidangbidang tanah tertentu ditetapkan untuk kepentingan umum, dan tanah ini tidak diperkenankan diletakan hak perseoranga.

d. Orang asing yang mau menari hasil dari tanah ulayat harus terlebih dahulu minta ijin dari kepala persekutuan, dan harus membayar uang pengakuan, dan setelah panen harus membayar uang sewa.

e. Larangan mengasingkan tanah yang termasuk tanah ulayat, artinya baik persekutuan maupun anggotanya tidak boleh memutus secara mutlak sebidang tanah ulayat sehingga persekutuan sama sekali hilang wewenangnya atas tanah tersebut ${ }^{7}$.

Berdasarkan hal tersebut maka yang boleh memanfaatkan tanah ulayat pada hakekatnya adalah masayarakat persekutuan hukum adatnya, yang diatur oleh pemangku adat, karena pemilikan terletak pada persekutuan hukum adat, persekutuanlah yang mengatur tentang hakhak perseorangan dan kepentingan persekutuan.

Dalam hal pemanfaatannya hak ulayat bagi masyarakat mempunyai dua fungsi yaitu :

a. Ke dalam. Menjamin kehidupan anggotanya dalam lingkungan wilayahnya untuk mengerjakan atau mengambil hasil dari tanah tersebut.

b. Ke luar. Pada dasarnya bagi yang bukan anggota persekutuan tidak berhak untuk mendapatkan sebidang tanah dalam wilayah tersebut. Apabila orang luar menghendakinya maka harus mendapatakan ijin dari kepala persekutuan, dan kalau diijinkan maka ia harus membayar uang masukan. Hak yang diberikan adalah hak pakai, yang tidak bisa diwariskan. Sebagai tandanya maka setiap habis panen diwajibkan kepada mereka untuk membayar uang sewa.

Wewenang penguasaan, tanggung jawab dan pengaturan pertanahan serta pengawasan dipegang oleh kepala persekutuan sebagai wilayah terutama tentang hak dan kewajiban masyarakat atas tanah demi terciptanya ketertiban dan kedamaian dalam masyarakat. Menurut Iman Soediyat pada hakekatnya hak ulayat merupakan :

a) Hak kepunyaan bersama masyarakat hukum adat sebagai kebulatan seluruh warga.

b) Hak terkuat masyarakat hukum adat atas tanah termasuk air, dan udara dalam lingkungan wilayah kekuasaannya yang pada asasnya tidak dapat dikurangi/ dipindahtangankan.

c) Hak yang memberikan kewenangan dan tugas kepada masyarakat hukum adat untuk melakukan usaha dan mengatur segala sesuatu mengenai tanah dalam hubungannya dengan manusia utuk kepentingan umum, kesejahteraan dan kebahagiaan hidup warga masyarakat. $^{8}$

\section{Hak Milik dan Hak Komunal}

Di dalam hak ulayat diperkenankan adanya hak perseorangan yang diawali dengan seseorang melakukan kegiatan di atas tanah tertentu. Kegiatan tersebut terus dilakukan seperti berladang bahkan menetap di sana sehingga terlihat adanya hubungan nyata seseorang dengan tanah. Namun apabila terjadi sebaliknya, maka hak ulayat semakin kuat, hubungan timbal balik penguasaan tanah tersebut sama dengan teori bola oleh Teer Haar, yaitu semakin kuat hak

\footnotetext{
7 Iman Soediyat, Masalah Hak Ulayat di Wilayat Bekas Keresidenan Madura, Prasaran dalam seminar Pengalaman Lapangan dan Kegunaan Hasil Penelitian Madura, 1977, hal 8

${ }^{8}$ Ibid Iman Soediyat, hal 20
} 
ulayat maka semakin menipis hak individu, dan apabila hak individu semakin kuat maka hak ulayat semakin menipis.

Konsep pola penguasaan dan pemilikan tanah adat yang seperti ini masih dijumpai di Kabupaten Kerinci atau Kota Sungai Penuh khususnya bagi masyarakat persekutuan hukum adatnya yang hendak mendirikan rumah, baik diatas tanah hak milik individu maupun tanah negeri. Prosedur mendirikan rumah ini disebut dengan ajun arah. Menurut adat Kerinci atau Kota Sungai Penuh, ajun arah dibagi dua yaitu :

1. Ajun arah dalam parit yang bersudut empat dan di luar lawang yang berkatup dua atau dalam hal ini disebut sebagai tanah yang berada di dalam lahek maka jatuh kepadanya hak pakai saja.

2. Ajun arah di luar parit yang bersudut empat dan di luar lawang yang berkatup dua, atau dalam hal ini adalah tanah yang berada di luar luhah atau lahek maka jatuh kepadanya hak milik, dimana sipemilik berhak menjual dan sebagainya terhadap tanah tersebut ${ }^{9}$

Ajun arah pengaturannya dilaksanakan oleh ninik mamak masing-masing luhah berdasarkan hukum adat. Dalam pelaksanaannya pada luhah atau lahek tiap-tiap ajun arah memiliki seorang tanggane tanah, yaitu saudara laki-laki dari pihak perempuan yang mengetahui secara persis tentang tanah tersebut. Dalam saluko adat dikatakan ; "Bak kato pepatah mengatokan; Adapun anak batino kamai kok baume lah bulih padoi. Kok mancahai lah bulih maeh. Lah tasedoik di hatai ta krang (ikrar) di lideah, talanca di kalang menjadi hutang. Ndok ngenak atak dengan ndok ngeak tiang dengan sabateang. Atak tempek batedeuh kok tiang basanda. Minta diajun minta diarah". Artinya " seperti kata pepatah mengatakan bahwa anak perempuan kami (dalam hal ini yang menerima waris di Adat Kerinci/Kota Sungai Penuh adalah anak perempuan. Jika ke sawah ada yang didapatkan, jika mencari didapatkan emas, telah tersebut di terikrar pula di lidah, tergelincir di waktu gelap menjadi hutang, ingin memakai atap yang selembar, ingin menegakkan yang sebatang, atap untuk berteduh, tiang untuk bersandar, minta diajun minta diarah. Seloko adat ini adalah dasar bagi pemuka adat dan persekutuan masyarakat hukum adat dalam melaksanakan ajun arah untuk mendirikan rumah. Ajun arah dipengaruhi oleh sistem kekerabatan matrilinial yang mereka anut, dimana ajun arah dan tanah ajun arah hanya diperuntukan untuk anak perempuan. Adapun syarat yang harus dipenuhi dalam pelaksanaan ajun arah adalah ;

1. Orang yang memohon ajun arah harus mengundang ninik mamak yang berkuasa penuh terhadap ajun arah terebut (apo gilou nyerou depati ninik mamak suhok pintau tindek asouk). Acara ini disebut mendudukan depati ninik mamak, dan harus memberikan beras seratus dan kerbau seekor.

2. Menjelaskan tanah yang akan diajun arah oleh ninik mamak.

3. Tanah yang akan dijun arah adalah tanah jelas statusnya.

4. Tanah tersebut oleh ninik mamak diperiksa kembali, batasnya, luasnya, dan kewajaran mendirikan rumah diatas tanah tersebut ${ }^{10}$

Pada dasarnya ajun arah ini diwajibkan kepada semua masyarakat yang tinggal dalam wilayah Kota Sungai Penuh, baik masyarakat persekutuan hukum adatnya maupun diluar itu. Bagi mereka yang bukan masyarakat persektuan hukum adat untuk mendirikan rumah, maka mereka harus minta izin kepada pemuka adat, dan harus mengisi cupak berupa emas sesemas sebagai tanda mereka masuk ke dalam wilayah adat Kota Sungai Penuh. Tujuan mengisi cupak adalah mengangkat status mereka menjadi anak batino dalam luhah tempat mereka tinggal.

Adapun sanksi bagi masyarakat yang tidak melaksanakan ajun arah dalam mendirikan rumah, maka dikenakah sanksi secara bertahap yang dalam seluko adat disebut, berdasarkan

\footnotetext{
${ }^{9}$ H. A. Rasyid Yakin, Menggali Adat Lama Pusaka Usang, di Sakti Alam Kerinci, Sungai Penuh, 1986, hal 41

${ }^{10}$ wawancara dengan Asmar Malik, Depati Santi Udo Pertamo Alam, Sungai Penuh 2 Juni 2019
} 
pada sko nan tigo takah, "Bak kato siak lengaih, barang siapo ngan ideak taau pada ngan hak mako nyo masok ka ngan bakakoi empak, yaitu :

1. Tegoran dari tengganai

2. Tegoran dari ninik mamak

3. Denda adat atau sanksi adat.

Sedangkan tanah ajun arah adalah tanah negeri atau tanah ulayat dalam lawang yang berkatub 2, parit yang bersudut empat yang dipelihara dan dijaga oleh pemangku adat (Jauh diulang, dekat dikenano). . Segala yang berkenaan dengan tanah ajun arah dikuasai dalam pengertian diatur, dan ditetapkan oleh pemangku adat yaitu depati, ninik mamak, alim ulama, orang tuo cerdik pandai yang dilakukan melalui musyawarah adat, dan berdasarkan hukum adat. Tanah ajun arah adalah tanah yang dikuasai oleh lembaga adat sesuai dengan pepatah adat yaitu "Negeri hargo kampong nan batuo, rumah nan bataganai", dipergunakan untuk kepentingan masyarakat untuk mendirikan rumah. Tanah ajun arah hanya diberikan kepada anak perempuan (anak batino), sesuai dengan seluko adatnya "Harto berat untuk batino, harto ringan dibawa jantan". Seluko adat ini dipengaruhi oleh sistem kekerabatan matrilinial yang mereka anut. Pengertian harta berat adalah berupa tanah, rumah, sawah, ladang, dan lumbung padi. Oleh sebab itu yang bisa mendapatkan tanah ajun arah adalah hanya anak perempuan.

Masa berlakunya tanah ajun arah adalah selama tanah negri tersebut masih dipergunakan sesuai dengan peruntukannya, yaitu rumah, dan selama tategak tiang rumah, walaupun rumah tersebut hampir rubuh, dan tidak didiami lagi. Apabila tidak ada lagi hal tersebut diatas maka habislah masa berlakunya penguasaan tanah ajun arah oleh individu. Setelah habis masa berlakunya, maka tanah tersebut kembali kepada tanah negeri atau menjadi tanah ulayat negri Kerinci atau Kota Sungai Penuh. Berdasarkan uraian diatas maka pada dasarnya tanah ajun arah adalah tanah negeri, atau tanah ulayat yang dikuasai oleh masyarakat persektuan hukum adatnya atas izin pemangku adat secara hukum adat dan berdasarkan hukum adat untuk mendirikan rumah bagi anak batino dengan hak pakai, selama masih sesuai dengan peruntukannya. Apabila tidak sesuai lagi dengan peruntukannya maka tanah tersebut kembali menjadi tanah negeri dan dimungkinkan orang lain untuk mendapatkan tanah ajun arah tersebut.

\section{Pelaksanaan Pendaftaran Tanah Sistematik Lengkap Terhadap Tanah Ajun Arah.}

Badan Pertanahan Nasional (BPN) adalah lembaga pemerintah nonkementerian yang melaksanakan tugas pemerintah di bidang pertanahan sesuai dengan ketentuan dan peraturan dan perundang-undangan. Pada masa pemerintahan Presiden Joko Widodo, fungsi dan tugas dari organisasi BPN dan Direktur Jendral Tata Ruang Kementerian Pekerjaan Umum digabung dalam satu lembaga kementerian yang bernama Kementerian Agraria dan Tata Ruang. Untuk menyelenggarakan tugas dan fungsi BPN di daerah, dibentuk Kantor wilayah BPN di provinsi dan Kantor Pertanahan di Kabupaten/ kota.

Dalam pelaksanaan fungsi dan tugas BPN kegiatan yang populer dan siknifikan adalah penyelenggaraan pendaftaran tanah. Pendaftaran tanah adalah kewajiban bagi pemerintah dan kewajiban bagi pemegang hak atas tanah. Oleh sebab itu pendaftaran adalah tanggung jawab pemerintah dan tanggung jawab semua pemegang hak atas tanah. Menurut Peraturan Pemerintah Republik Indonesia Nomor 24 Tahun 1997, tentang Pendaftaran Tanah, Pasal 1 ayat (1), Pendaftaran tanah adalah rangkaian kegiatan yang dilakukan oleh pemerintah secerara terus menerus, berkesinambungan dan teratur, meliputi pengumpulan, pembukuan, dan penyajian, serta pemeliharaan data fisik dan data yuridis, dalam bentuk peta, dan daftar mengenai bidang-bidang tanah dan satuan rumah susun, termasuk pemberian surat tanda bukti haknya bagi bidang-bidang tanah yang sudah hakknya dan hak milik atas satuan rumah sus-un serta hak-hak tertentu yang membebaninya. Pasal 1 ayat (6), Data fisik adalah keterangan 
mengenai letak, batas, dan luas bidang tanah dan satuan rumah susun yang didaftar, termasuk keterangan mengenai adanya bangunan diatasnya. Pasal 1 ayat (7), Data yuridis adalah keterangan mengenai status hukum bidang tanah dan satuan rumah susun yang didaftar, pemegang haknya dan hak pihak lain serta beban-beban lain yang membebaninya.

Pasal 3, Tujuan pendaftaran tanah adalah :

a. Untuk memberikan kepastian hukum dan perlindungan hukum kepada pemegang hak atas tanah, bidang tanah satuan rumah susun dan hak-hak lain yang terdaftar agar dapat membuktikan dirinya sebagai pemegang hak yang bersangkutan.

b. Untuk menyediakan informasi kepada pihak-pihak yang berkepentingan termasuk pemerintah agar dengan mudah dapat memperoleh data yang diperlukan dalam mengadakan perbuatan hukum mengenai bidang tanah dan satuan rumah susun yang sudah terdaftar.

c. Untuk menyelenggarakan tertib administrasi pertanahan.

Pendaftaran tanah menghendaki adanya kepastian hukum, yaitu kepastian akan subjek hukum, objek hukum, perbuatan hukum, dan hubungan hukum. Oleh sebab itu dalam penyelenggaran pendaftaran tanah syarat tersebut harus dipenuhi. Kalau ada salah satu syarat itu tidak dipenuhi, pendaftaran tanah tidak bisa dilaksanakan.

Selama ini pendaftaran tanah berlangsung sangat lambat, karena pemerintah melaksanakan prinsip sistem pendaftaran negatif yang dilakukan secara sporadis, yaitu pendaftaran tanah dilakukan terhadap orang yang mengajukan pendaftaran tanah. Disamping itu dibantu dengan PRONA yang dilakukan setiap hari ulang tahun Hukum Agraria tiap-tiap tanggal 24 September. Namun demikian pendaftaran tanah berjalan dengan lambat, dan Indonesia akan bisa mencapai sertifikasi tanah secara menyeluruh sekitar 200 tahun lagi.

Untuk mengatasi lambatnya pendaftaran tanah maka pada masa pemerintahan presiden Joko Widodo dibuat Kementerian baru bernama Kementerian Agraria dan Tata Ruang Indonesia pada tanggal 27 Oktober 2014, dimana BPN meluncurkan program yang sangat populer yaitu Program Pendaftaran Tanah Sistematik Lengkap atau yang lebih dikenal dengan PTSL. Program ini untuk menyisir seluruh wilayah terdata melalui mekanisme sertifikasi secara keseluruhan. Program ini diharapkan dapat mempercepat memenuhi kebutuhan masyarakat akan legalitas sebuah investasi.

PTSL mengatasi sistem pendaftaran negatif yang hanya menunggu inisiatif masyarakat, bisa berkomodir dengan mekanisme jemput bola. Tim Satgas BPN yang berpusat disetiap kantor kelurahan daerah nantinya akan bekerja sama dengan kelurahan untuk mendata wilayah yang belum disertifikat. Program ini melayani seluruh masyarakat baik yang mampu maupun yang tidak mampu. Segala pembiyaan administrasi di Kantor BPN untuk mekanisme sertifikasi seperti biaya ukur, biaya panitia pemeriksa tanah sampai biaya administrasi, diseluruh cabang di Indonesia dibiayai oleh BPN.

Menurut Peraturan Mentri Agraria dan Tata Ruang/Kepala Badan Pertanahan Nasional Nomor 35 Tahun 2016, tentang Percepatan Pelaksanaan Pendaftaran Tanah Sistematik. Pasal 1 ayat (1), Pendaftaran tanah Sistematik Lengkap yang selanjutnya disingkat PTSL adalah kegiatan Pendaftaran Tanah untuk pertama kali yang dilakukan secara serentak bagi semua objek Pendaftaran Tanah di seluruh wilayah Republik Indonesia dalam suatu wilayah desa/kelurahan atau nama lainnya yang setingkat dengan itu, yang melputi pengumpulan dan penetapan kebenaran data fisik dan data yuridis mengenai satu atau beberapa obyek Pendaftaran Tanah untuk keperluan pendaftarannya.

Pelaksanaan PTSL bertujuan untuk mempercepat pemberian kepastian hukum dan perlindungan hukum Hak Atas Tanah masyarakat secara pasti, sederhana, cepat, lancar, aman, adil, merata dan terbuka serta akuntabel, sehingga dapat meningkatkan kesejahteraan dan kemakmuran masyarakat dan ekonomi negara, serta mengurangi dan mencegah sengketa dan 
konflik pertanahan. Sedangkan objek PTSL meliputi seluruh bidang tanah tanpa terkecuali, baik bdang tanah yang belum ada hak atas tanahnya maupun bidang tanah hak, baik merupakan tanah aset pemerintah pusat/pemerintah daerah, tanah Milik Badan Usaha Negara/Badan Usaha Milik Daerah, Tanah Desa, Tanah Negara, Tanah Masyaraskat Hukum Adat, Tanah Objek Landreform, dan bidang tanah lainnya.

Menurut bapak Gustizar, S.H. persyaratan yang harus diajukan oleh masyarakat untuk ikut dalam program PTSL, misalnya harus melengkapi keterangan waris, melengkapi suratsurat dari kelurahan yang menjadi tanggung jawab pemohon, peserta harus melengkapi berkas yang disyarakatkan oleh BPN, jika semua dokumen sudah lengkap, maka menunggu petugas ukur untuk memeriksa ke lapangan. Kelengkapan dokumen pendukung keabsahan dokumen seperti surat penguasaan tanah secara fisik, surat bahwa lahan tersebut tidak bersengketa dan kelengkapannya, pajak yang harus dilengkapi, KTP. Apabila data yuridis lengkap kemudian diukur tanahnya. Masyarakat yang mengajukan sertiikasi tersebut harus memasang patok besi atau patok cor semen untuk mempermudah petugas $\mathrm{BPN}^{11}$.

Menurut Bapak Gustizar, Presiden Indonesia mentargetkan 126 juta bidang tanah sudah bersertifikat pada tahun 2024. Untuk Kota Sungai Penuh BPN Indonesia mentargetkan 6000 (enam ribu) tanah sudah disertifikatkan, pada tahun 2017, 8000 (delapan ribu) tanah sudah disertifikasi, 9000 (sembilan ribu) tanah sudah disertifikasikan pada tahun 2019. Untuk Kota Sungai Penuh target tersebut belum bisa dipenuhi oleh karena terkendala dengan sulit menentukan subjek hukumnya khususnya tanah yang dikuasai dan dimilki berdasarkan hukum adat. Penguasaaan dan pemilikan tanah tersebut antara lain adalah pola penguasaan tanah secara gilir ganti dan tanah ajun $\operatorname{arah}^{12}$.

Menurut Asmar Malik ;

a. Tanah ajun arah harus untuk rumah.

b. Ajun arah diperlakukan untuk tanah hak milik maupun tanah negeri.

c. Lama penguasaan atau hak pakai selagi tiang masih tategak dan tidak bisa dialihkan (digulung arah).

d. Yang berhak mengajun dan mengarah adalah ninik mamak.

e. Ninik mamak adalah pemimpin luhah.

f. Di kota Sungai Penuh ada 6 (enam luhah) yang masing-masing mempunyai tanah ajun arah negeri, yaitu :

1) Luhah Datuk Singo Rapi Putih.

2) Luhah Datuk Pemangku Rajo

3) Luhah Datuk Rio Temenggung.

4) Luhah Rio Jayo.

5) Luhah Rio Mediho.

6) Luhah Dusun Bernik ${ }^{13}$

Menurut Asmar Malik Adapun tata cara untuk mendapatkan tanah ajun arah adalah :

a. Orang yang berkehendak harus mengundang Ninik Mamak, dan Tengganai.

b. Menyampaikan maksud atau hajat yang berkehendak kepada Ninik Mamak dan Tengganai untuk meminta ajun arah.

c. Menunjung tanlokasi ah yang akan diajun arah yaitu tanah kosong yang tidak ada tiang rumah.

d. Setelah melalui tata cara adat, kemudian Ninik Mamak dan Tengganai melihat lokasi yang dimaksudkan oleh orang yang berkehendak.

e. Kalau tidak ada tiang rumah, baru Ninik Mamak memberi ajaun arah dengan ;

\footnotetext{
${ }^{11}$ wawancara dengan Bapak Gustizar, S.H. Kepala BPN Kota Sungai Penuh, tanggal 2 Juni 2019

12 wawancara dengan Bapak Gustizar Kepala BPN Kota Sungai Penuh tanggal 2 Juni 2019

${ }^{13}$ Wawancara dengan Asmar Malik Depati Santi Udo Pertamo Alam, Sungai Penuh, tanggal 19 April 2019
} 
1) Lemang

2) Pisang

3) Menghanguskan meh seemeh.

f. Ketentuan huruf e, dilakukan secaara adat dengan parno dari tengganai kepada ninik mamak.

Menurut Gustizar, S.H.. Kota Sungai Penuh adalah salah satu daerah di Indonesia yang tanah adatnya masih utuh yaitu ditandai dengan ;

a. Masih adanya wilayah adat.

b. Masih adanya pemangku adat atau fungsionaris adat.

c. Masih adanya hukum adat yang berlaku sampai sekarang.

d. Masih adanya masyarakat persekutuah hukum adat yang patuh dengan hukum adatnya (Wawancara dengan bapak Gustizar, Kepala BPN Kota Sungai Penuh, Sungai Penuh 2 Juni 2019).

Undang-undang Nomor 5 Tahun 1960, pada Pasal 3 dan Pasal 5, pada dasarnya mengakui keberadaan tanah yang dikuasai dan diatur oleh hukum adat termasuk tanah ulayat seperti tana ajun arah di Kota Sungai Penuh sepanjang tidak bertantangan dengan kepentingan bangsa dan negara dan peraturan yang berada diatasnya. Dalam kondisi ini BPN Kota Sungai Penuh mengambIl suatu kebijakan yaitu bagaimana mempertahankan hukum tanah adat agar tidak termakan zaman dan juga tetap melaksanakan ketentuan yang berkenaan dengan Hukum Pertanahan Nasional.

Kebijakan yang dilakukan oleh BPN Kota Sungai Penuh adalah mempertahankan keberadaan tanah ajun arah. Adapun manfaat bagi BPN Kota Sungai Penuh adalah;

a. Peringatan bagi bagi masyarakat yang bermaksud untuk mensertifikatkan tanah diwilayah tanah adat.

b. Dasar bagi BPN untuk menolak pendaftaran tanah tersebut berdasarkan peta tanah adat $^{14}$.

Bagi orang adat pemetaan ini sangat berguna sebagai informasi objek tanah adat dan kepemilikannya. Dalam pelaksanaan PTSL produk Surat Hak Atas Tanah (SHT) berupa :

a. Sertifikat untuk tanah hak milik.

b. Pengukuran tanah terhadap tanah yang bersengketa, pengukuran ini hanya menghasilkan peta tanah, tapi tidak disertifikatkan.

c. Pengukuran tanah bagi yang mempunyai alas hak, tapi tidak disertifikatkan yaitu;

1) Tanah sawah gilir ganti

2) Tanah ajun arah

3) Tanah yang tidak tahu siapa pemiliknya.

d. Bagi sertifikat lama yang sudah ada yang bersifat situasai tanah, tapi belum bersifat kadaster, hal yang dilakukan adalah perbaikan kwalitas data.

Tujuan PTSL adalah untuk menentukan kepastian hukum, dan menghindari konflik batas. Sampai saat ini atau 2019, BPN Kota Sungai Penuh telah berhasil memetakan tanah ajun arah:

a. Kelurhan Sungai Penuh.

b. Dusun Baru 150 persil

c. Sumur Anyir 60 persil

d. Desa Koto Lolo 120 persil

e. Desa Simpang Tiga Rawang

f. Desa Kota Tuo Tanah Kampung.

Ada 560 tanah ajun arah di Kota Sungai Penuh yang luas per persilnya rata-rata adalah $6 \mathrm{~m}$ x 9m, atau 9m x 10m. Sampai bulan Juni 2019 baru $30 \%$ tanah ajun arah yang masuk ke dalam data PTSL. Berdasarkan data tersebut, maka tanah ajun arah sampai pada tahap

${ }^{14}$ Wawancara dengan bapak Gustizar, S.H., Kepala BPN Kota Sungai Penuh, Sungai Penuh 2 Juni 2019 
pemetaan, dan tidak diterbitkan sertifikat. Walaupun demikian sudah merupakan suatu kemajuan dalam kepastian hak dan kepastian data fisik, dan bisa menjadi pedoman bagi masyarakat dan BPN Kota Sungai Penuh dalam pendaftaran hak atas tanah, dan juga bisa dijadikan pedoman untuk menyelesaikan konflik pertanahan. BPN Kota Sungai Penuh memmpunyai prinsip "bahwa Hukum Tanah Adat di Kota Sungai Penuh harus diakui eksistensinya dan dihargai karena merupakan ketentuan adat yang melekat pada persekutuan masyarakat hukum adat, dan tetap melaksanakan ketentuan Hukum Agraria Nasional.

\section{Kesimpulan:}

\section{KESIMPULAN DAN SARAN}

1. Tanah ajun arah adalah tanah negeri atau tanah ulayat yang diatur oleh lembaga adat dan dikuasai oleh pemangku adat yang ditetapkan oleh depati dan ninik mamak, alim ulama, orang tuo cerdik pandai melalui musyawarah adat. Pola penguasaan tanah ajun arah dipengaruhi oleh sistem kekerabatan matrilinial yang membedakan antara anak laki-laki dan perempuan. Tanah ajun arah adalah tanah negeri yang boleh dipakai oleh anak batino saja untuk mendirikan rumah. Penguasaan tanah tersebut masih berlangsung sepanjang masih terbukti secara fisik sesuai dengan peruntukannya.

2. Hukum Agraria Nasional Indonesia membenarkan adanya penguasaan tanah secara hukum adat termasuk tanah ajun arah sepanjang tidak bertantangan dengan praturan perundangan yang ada diatasnya, dan tidak bertantangan dengan kepentingan bangsa dan negara. Pelaksanaan program pemerintah Indonesia dalam rangka Pendaftaran Tanah Sistematik Lengkap tetap terlaksana walaupun hanya sampai pada tahap pemetaan, karena tanah ajun arah bukanlah tanah individu, dan tanah ajun arah masih bisa diberikan oleh pemangku adat kepada orang lain bila peruntukan untuk mendirikan rumah tersebut tidak kelihatan lagi. Kondisi ini menyebabkan sulit untuk menentukan kepastian hukum tentang subjek hukum sebagai salah satu sarat untuk Pendaftaran Tanah Sistem Lengkap di Kota Sungai Penuh. Suatu hal positif pada pola penguasa tanah ajun arah ini, menyebabkan tanah adat tidak beralih kepada pihak diluar persekutuan hukum adat, karena orang diluar persekutan Saran hukum adat tidak punya hak untuk menguasai dan memiliki tanah ajun arah.

Agar Pemerintah atau BPN Kota Sungai Penuh melanjutkan proses pemetaan tersebut dan mengkaji untuk kemungkinan diterbitkannya sertifikat khusus atas nama jabatan Ketua Adat atau sejenisnya yang mewakili persekutuan masyarakat hukum adat, dengan mengadopsi hak menguasai dari negara seperti yang terdapat dalam Pasal 2 ayat (2) UUPA.

\section{DAFTAR PUSTAKA}

Abdurrahman, SH., Hukum Adat Menurut Perundang-undangan Republik Indonesia, Cendana Press, Jakarta, 1984.

Benyamin White dkk, Makalah disampaikan dalam Lokakarya Hukum Tanah, untuk Lembagalembaga Swasta Pembina Swadaya Masyarakat Desa, diselenggarakan oleh Sekretariat Bina Desa bekerjasama dengan HKTI, Jakarta 28 Maret 1980

Djakfar, Idris, Laporan Penelitian Hukum Waris Adat Masyarakat Kerinci, Fakultas Hukum Universitaas Jambi.

Doner, Peter, Land Reform and Economic Develop, Penguin Books Australia Ltd, 1972.

Haar, Teer, Beginselen Stelsel van het Aadatrech, JB, Walter Gronengen, Jakarta 1950

L.P. Hasibuan Gelar Patuan Daulat Baginda Nalobi, Hukum Agraria Menurut Adat

Dalihan Natolu, Medan ; Oktober 1989.

Muhammad, Bushar. SH., Pokok pokok Hukum Adat, Pradnya Paramita, Jakarta 1981 
Ningrat, Kuncoro, Kebudayaan Mentalitet dan Pembangunan, Jakarta PT Gramedia, 1987.

Nalobi, LPH Gelar Patuan Daulat Baginda, Hukum Agraria Menurut Adat Dalihan Natolu, Medan 1989.

Ningrat, Kuncoro, Kebudayaan Mentalitet dan Pembangunan, Jakarta PT Gramedia, 1987.

Santoso, Urip. Hukum Agraria Kajian Komprehensif, Kencana, Jakarta 2012.

Saragih, Jaren. Pengantar Hukum Adat, Edisi II, Taristo, Bandung, 1984.

Soediyat, Iman. Masalah Hak Ulayat di Wilayat Bekas Keresidenan Madura, Prasaran dalam seminar Pengalaman Lapangan dan Kegunaan Hasil Penelitian Madura, 1977.

Yakin, Rashid. Menggali Adat Lama Pusaka Usang, di Sakti Alam Kerinci, Sungai Penuh, 1986 , 